\title{
Stalin's German Policy After Stalin
}

Stalin's "last word" on German reunification was contained in the Soviet diplomatic note of March 10, 1952, which proposed a peace treaty with Germany. Until the middle of 1953, Stalin's heirs continued to press for reunification on the basis of the 1952 note. The East German uprising of June 17, 1953 (which is commemorated in West Germany, with unintended irony, as the "Day of German Unity") marked the de facto termination of the Soviet reunification initiative. ${ }^{1}$ As a result of the uprising, the rulers of the Soviet Union and East Germany were forced to place greater emphasis on the consolidation of the Communist regime in the GDR - that is, the stability of East Germany required policies explicitly directed toward the development of a separate, socialist East German state. Thus, the uprising and the subsequent Soviet intervention further undermined the credibility of an already questionable Soviet reunification initiative.

Would reunification have been possible if there had been no uprising? I will argue in this paper that, on the basis of the Soviet note of March 10, 1952, little likelihood of reunification existed. While the 1953 uprising served as a reminder of important barriers to reunification, these barriers were not created by the uprising, they were inherent in the situation in Europe and in Soviet policy. The following argument is presented in three parts: the first is a brief consideration of Stalin's German policy in 1952; the second is an examination of the terms of Stalin's 1952 reunification proposal ; and the third is an explanation of the link between the Soviet stand on reunification and the 1953 crisis in the GDR that culminated in the June uprising.

The Soviet position on German reunification during the early 1950s was a response to the prospect of West Germany's integration into the Western alliance system. While the possibility of German rearmament had been discussed from time to time in the West as the Cold War developed, the actual decision to rearm West Germany was not made until after the outbreak of the Korean War. ${ }^{2}$ In September 1950, the Western foreign ministers at the NATO Council meeting in New York agreed in principle to permit the creation of West German armed forces. $^{3}$ The framework for West German rearmament was to be the European Defense Community (EDC), a highly integrated international force. After protracted and complicated negotiations, the EDC treaty was signed in May 1952 by the United States, Great Britain, France, and the Federal Republic of Germany. At that time the difficult struggle for parliamentary ratification of the agreement by France and West Germany still lay ahead.

1. The change in Soviet policy on reunification after June 17 was subtle but unmistakable (see, for example, Gerhard Wettig, Die Entmilitarisierung und Wiederbewaffnung Deutschlands 1943-1955 [Munich: R. Oldenbourg Verlag, 1967], p. 100).

2. Walter LaFeber, America, Russia, and the Cold War 1945-1971 (New York: John Wiley and Sons, 1971), pp. 80 and 102.

3. New York Times, September 19, 1950. 
The Eastern bloc responded swiftly to the decision.to proceed with German rearmament and the creation of EDC. On October 20 and 21, 1950, East European foreign ministers met in Prague (this was, incidentally, the first international meeting at which the government of the GDR was fully represented ${ }^{4}$ ). The conference issued a call for the signing of a peace treaty with Germany, to be followed within one year by the withdrawal of all occupation troops. ${ }^{5}$ The conference communique proposed the formation of an all-German council in which East and West Germany would be equally represented. This council was to prepare for the creation of a provisional all-German government, which would then participate in the drafting of the peace treaty.

On November 30, 1950, East German Prime Minister Grotewohl, in a letter to Chancellor Adenauer, reiterated the proposals of the Prague foreign ministers' conference. The "Grotewohl letter" was the opening salvo of a campaign that lasted about two years, in which East German officials bombarded their West German counterparts with proposals for direct East-West German contacts leading to the establishment of a provisional all-German government. ${ }^{\circ}$ This phase of East European German policy was dominated by the slogan "Germans, sit down at one table." However, all such proposals were rejected by the Western powers and especially by West German Chancellor Adenauer. The West insisted that, because the East German government was not an elected government, it could not represent East Germany in an all-German council or in any other body. In fact, the East German government was seen as an illegitimate puppet of the Soviet Union. The Western position on reunification was clear and simple, if unrealistic under the circumstances: Germany could be reunified only on the basis of free and secret elections held throughout the country.

Despite vigorous Soviet opposition and considerable controversy within the Western alliance and West Germany, it was apparent in early 1952 that the European Defense Community treaty would be signed. The NATO conference held in Lisbon in February 1952 confirmed the importance of German troops in Western planning for the defense of Europe. Stalin's last word, the Soviet note of March 10,1952, was, then, a response to the imminent realization of the EDC.

The note reiterated the demand for the speedy signing of a German peace treaty which, among other things, would safeguard "the legitimate national interests of the German people." 8 The treaty was to be signed by representatives of an "all-German government," presumably the government envisioned by the 1950 Prague conference and the Grotewohl letter. After the signing of the peace treaty, the united Germany was to be permitted to maintain land, sea, and air forces for its own defense. But the new Germany was to be forbidden, under

4. DDR Werden und Wachsen: Zur Geschichte der Deutschen Demokratischen Republik, Akademie der Wissenschaften der DDR, Zentralinstitut für Geschichte (Berlin: Dietz Verlag, 1974), p. 177.

5. Pravda, October 22, 1950; and New York Times, October 22, 1950.

6. DDR Werden und Wachsen, pp. 191-92.

7. Wolfram F. Hanrieder, West German Foreign Policy 1949-1963 (Stanford: Stanford University Press, 1967), pp. 67-74.

8. Pravda, March 11, 1952; and Izvestiia, March 11, 1952 (translated in Current Digest of the Soviet Press, 4, no. 7 [1952]: 7). 
the terms of the Soviet draft peace treaty, to join any alliance directed against a member of the former anti-Hitler coalition, a clear reference to the EDC. ${ }^{9}$ The Soviet note thus seemed to say that the USSR would prefer the creation of a unified, armed, and neutral German state to the integration of West Germany into the Western alliance system.

In mounting the attack against West European integration and West German rearmament, the Soviet Union was able to choose between the two vulnerable points in the Western alliance system, the French fear of Germany's resurgence and the German hope for reunification. The Russians chose to concentrate on the Germans.

During the early 1950s the Federal Republic of Germany represented a weak link in the proposed Western alliance for two reasons. First, the regime represented by the government in Bonn had only recently been constituted. In a sense it had been imposed on the West German public by the victory of the Allies over nazism. The Bonn government did not enjoy the historical legitimacy of the governments in London, Paris, and Washington. In addition, there was doubt about the attachment of West German voters to the particular form of government in the FRG-parliamentary democracy. The only previous German experience with this kind of regime, the Weimar Republic, had failed disastrously. The government of the Federal Republic, based on previously unsuccessful political principles, ruled over a truncated Germany from a small town on the Rhine rather than from the historical capital. It seemed likely that not only West Germany's foreign policy but the form of the regime itself would depend on West Germany's continuing involvement with the Western allies. In other words, the EDC, which was initially intended to provide for military defense, was also important in guiding the overall future development of the country.

The second factor in West Germany's vulnerability was the division of Germany. West Germany was the one Western power with a major objective -reunification-that could be satisfied peacefully only with the acquiescence of the USSR. The Russians insisted, therefore, that West German entry into the Western alliance would destroy any hope of reunification. Stalin thus hoped to appeal to nationalist sentiment in West Germany as well as to liberal, antimilitarist, and pacifist elements. The reunification offer of March 10 was an alternative to West German membership in the EDC and hence to the existence of the EDC altogether. Recognizing the Soviets' intention, the Western governments rejected the Soviet offer ${ }^{10}$ and proceeded to sign the EDC treaty and to press for ratification.

Had the West chosen to pursue the Soviet initiative, the EDC would have had to be set aside indefinitely, with almost no prospect of ever bringing it back to life. The incipient EDC was, after all, still a fragile achievement in 1952. Only with difficulty had the Western powers been able to reach agreement on the particulars of the treaty. The negotiations had been doubly complicated: first, it had been necessary to reconcile the interests of the governments involved;

9. East Germany's Walter Ulbricht put the case more strongly. In May 1952 he asserted that a united Germany must maintain a "firm friendship with the Soviet Union" (see Wettig, Die Entmilitarisierung, p. 512).

10. New York Times, April 8, 1952; and Dean Acheson, Present at the Creation (New York: W. W. Norton, 1969), pp. 629-32. 
second, the struggle for parliamentary ratification within each country required that each government reconcile the terms of the agreement with the hopes and fears of its own electorate (the West German hope for full sovereignty, the French fear of a German resurgence).

The Soviet offer was therefore viewed by the Western powers as a tactic intended to delay and disrupt the integration of West Germany into the Western alliance system. This was similar to the view subsequently taken by East German historians. The authoritative history of the GDR notes that although East European efforts toward "the democratic reunification of Germany in the early 1950 s were not ultimately successful, neither were they in vain." These efforts "complicated and delayed the arming of the FRG and its incorporation into NATO."11 In connection with the continuation of the Soviet reunification initiative after the death of Stalin, the same source observes that "the goal of the Soviet peace program was to prevent the arming of the FRG and its incorporation into NATO."12

In short, the Soviet reunification offer of 1952 was designed to derive maximum advantage from the differences between the Western camp and the Eastern camp. In the West the structure of international agreements constituted the actual basis of relations among the allies. The Western alliance was based on agreements negotiated by governments dependent on electoral majorities. This was not true of relations between the USSR and the satellites, including East Germany. Soviet European policy did not depend to any significant degree on consultations with allies or the preservation of electoral majorities. The Soviet attack on the formal alliance structure of the West constituted an attack on the actual alliance structure, while the "alliance" between the Soviet Union and the GDR existed quite independently of any formal agreements.

It is important to remember that the primary objective of Soviet German policy was not the unification of Germany but the prevention of West German entry into the Western alliance. German unity was never an end in itself for the Russians; it was, at best, a price the USSR was willing to pay for the pursuit of other objectives. Thus, the purpose of this study is not to analyze hypothetical arrangements under which Germany might have been reunified. It will be sufficient to consider what advantage the Soviet Union gained from the division of Germany and what countervailing factors might have moved the Russians to contemplate surrendering that advantage.

The Soviet advantage in maintaining a separate East German state was twofold. First, the Russians enjoyed the material benefits of alliance with the GDR - the East German contribution to the economic and military potential of the Eastern bloc. Second, the GDR provided the Soviet Union with an avenue of entry into the politics of West Germany and hence Western Europe and the Atlantic alliance.

If there was serious Soviet interest in reunification, it must have been based on one or more of the following considerations: First, there might have been doubts about the long-term viability of the East German regime, separated artificially from the bulk of Germany and burdened with an alien presence in 
the center of the country (West Berlin). There might have been doubts about the country's economic prospects, although even in 1952 it should have been apparent that an industrialized country with seventeen million people could become a substantial economic power. Any doubts about East Germany's future viability were surely political rather than economic, stemming from the unpopularity of the regime, the proximity of West Germany and West Berlin, and the continued loss of population through the capital. The Soviet Union may have feared that the maintenance of Communist rule in East Germany would be more complicated than in the other countries of Eastern Europe.

Second, the USSR might have expected to be compensated for the loss of East Germany with a greater Soviet voice in the affairs of a united Germanyin short, the advantages of what later came to be called "Finlandization." But there are important differences between the situation in Finland and that in Germany. Finland's non-Communist government is highly vulnerable to Soviet pressure because the country is small and weak. It is located on the border of the Soviet Union and is geographically isolated from the major Western powers. A unified Germany, by contrast, would have been neither small nor weak nor geographically isolated. It is possible, of course, that the collapse of the Western alliance through the withdrawal of the FRG might have forced a united German government to seek wholesale accommodation with the Soviet Union. But it is equally likely that the new Germany, neutrality notwithstanding, would have become a major anti-Soviet power.

Third, the unification of Germany might have been viewed as part of a general settlement of the Cold War, easing international tensions and establishing a durable détente. Apart from the question of whether the USSR desired these goals, it is necessary to ask whether German reunification was necessary to achieve détente and whether, in fact, it would have done so. The Russians could hardly have imagined that German reunification was a high priority for the Western allies or that the division of Germany in itself represented a serious irritant to the West. Subsequent developments in Europe demonstrated that the reunification of Germany was not a necessary precondition for détente.

The Soviet declaratory position on reunification thus differed in one important respect from that of the West. The Western position (joint elections and a sovereign Germany free to conclude alliances) described conditions under which the West would clearly have been prepared to accept reunification. Because the Western advantage was obvious, the USSR could not have been expected to go along with this proposal. But the Soviet offer was so fraught with risks for both the West and the USSR that the Russians themselves might not have permitted reunification on the terms described in their own diplomatic note.

If the Soviet advantage from reunification was so questionable and the risk so high, why did Stalin put forth the proposal? The answer is that Stalin did not need to decide in advance whether he was prepared ultimately to permit reunification. The proposal was designed so that the first steps toward reunification would have required major concessions by the West and virtually none by the USSR. The Russians could have cashiered Western concessions during several early steps of the reunification process without making an irrevocable commitment to reunification. First the West would have had to shelve the EDC. In view of the complexity of the EDC negotiations-the difficulty of the struggle 
for ratification in France and the possibility of opposition from the Social Democratic Party (SPD) in Germany-and the importance attached by the United States to European integration as a condition of continued American involvement in Europe, the Soviet advantage would have been considerable even if the talks had never gotten off the ground. The next step would have been the drafting of a German peace treaty or preparation for elections. (The Soviet position on the exact order was unclear.) In either case, representatives of the two German governments would have been involved. This would also have conistituted a major concession by the West in recognizing representatives of the government of the GDR, even provisionally, as spokesmen for the East German population. The Soviet Union would thus have achieved a measure of Western recognition of the GDR. The final step would have been general elections in all of Germany, and only at this point would the Soviet Union have needed to decide whether it was seriously interested in reunification. The USSR proposed to abolish all travel restrictions between the two parts of Germany three months before the elections and to permit free campaigning throughout the country by all recognized parties and groups. The polling places were to be supervised by representatives of the four powers (in contrast to United Nations observers, as proposed by the West).$^{13}$

The Russians stood by their insistence that German elections be open to "democratic and peaceful" groups but closed to "imperialists and revanchists." As these terms were normally used in Soviet and East German statements, every organization in the GDR was called "democratic and peaceful," while "imperialists and revanchists" referred to all the ruling parties of the FRG (Christian Democratic Union, Christian Social Union, and Free Democratic Party of Germany) as well as most of the opposition (SPD). ${ }^{14}$ Only after a unified German government had been constituted as the result of general elections, were occupation troops to be withdrawn from both parts of Germany. The Soviet commitment to reunification would not have become irrevocable until troops were actually withdrawn, since, in contrast to West Germany, the occupation troops provided the real basis of the East German regime.

The order of steps toward reunification thus resulted in maximum Soviet advantage because of the central difference between the GDR and the FRG, namely, that only West Germany had an elected government. The numerous declaratory and diplomatic concessions in the early phases of reunification would have affected primarily the political atmosphere and possibly election results in the West.

Stalin died on March 5, 1953. Although his death led to no official change in the Soviet position on German reunification as set forth in the 1952 note, that position became more credible in the context of new post-Stalin Soviet

13. The United Nations actually appointed observers to examine the conditions for free elections in Germany. Poland refused to participate in the observer mission, and in 1952 the GDR refused permission for the observers to enter the country. The Soviet rejection of a United Nations role (which was based on a technicality) reinforced suspicions that the Russians intended to meddle in the elections.

14. Gerd Meyer, Die sowjetische Deutschlandpolitik im Jahre 1952 (Cologne: Böhlau Verlag, 1970), pp. 78-79. 
policies toward the GDR. Western officials expected, ${ }^{15}$ and East European leaders seemed to promise, a renewed Soviet push for German reunification after the death of Stalin. East Germany's Walter Ulbricht, for example, in a call for Big Four reunification talks, claimed that the USSR had proved its sincerity by its efforts to end the Korean War (that is, by the most dramatic post-Stalin shift in Soviet foreign policy). ${ }^{16}$

Meanwhile, the West German Bundestag (the lower house) ratified the EDC treaty on March 19, 1953, and the Bundesrat (the upper house) ratified the treaty on May 15. Having lost the battle to prevent ratification, the USSR's last hope to stop the EDC in Germany became the West German elections scheduled for September 1953. Soviet and East German statements continued to portray Konrad Adenauer as the enemy of reunification, in the hope that West German voters would repudiate the EDC at the polls. But in the course of the summer, the Soviet reunification drive became entangled with domestic difficulties in the GDR.

In assessing the East German events of 1953, it is important to recall that at the time of Stalin's death the GDR was still something of an anomaly in Soviet-dominated Eastern Europe. The East German regime had not yet completely lost the provisional character that distinguished it from the other Soviet satellites. It was the only satellite not classified as a "people's democracy." Until October 1949, the GDR had not even been a country but merely an occupied territory, and the Russians continued to exercise numerous occupation rights at the time of Stalin's death. There were also important differences in economic and social structure between the GDR and the rest of Eastern Europe. While the other satellites had launched programs of rapid collectivization and industrialization in 1949 and 1950, no such program was adopted in the GDR until the Second Party Conference in July 1952. The "construction of socialism," as the program of the Second Party Conference was called, was thus barely under way when Stalin died.

The death of Stalin was followed in the USSR by the "thaw." The temporary leadership vacuum in the Kremlin gave rise to intense factional intrigue in East Berlin as well as in Moscow, with Soviet German policy emerging as a major issue. The details of the power struggle are beyond the scope of this study; they have been discussed elsewhere. ${ }^{17}$ For the purpose of the present account it is sufficient to note that, as early as April 1953, the new Kremlin leadership began to urge the GDR to abandon the harsh policies associated with the "construction of socialism," despite the desire of First Secretary Ulbricht to complete the Stalinist transformation envisioned by the Second Party Conference. On June 10, 1953, in response to a Soviet ultimatum, the East German Politburo was forced to promulgate the reform package that came to be known as the "New Course" and which signaled a retreat from the intensified austerity and political repression of the past year. In conjunction with the New Course,

15. New York Times, March 15, 1953, and April 7, 1953.

16. Ibid., April 16, 1953.

17. For a more detailed account of Soviet-GDR tensions during this period, see Victor Baras, "Beria's Fall and Ulbricht's Survival," Sovict Studies, 27, no. 3 (July 1975) : 381-95. (The article contains an important error at the bottom of page 387 . The date should read "27 July 1953.") 
an internal party directive ordered the deletion of the slogan "construction of socialism" from all official materials. ${ }^{18}$

Authoritative discussions of the New Course in the GDR emphasized the connection between the international situation and new domestic policies, and thus the New Course was described as the concomitant of "recent" Soviet peace initiatives (that is, since the death of Stalin). The shift in resources from heavy industry to the consumer sector was said to be possible because of the relaxation of international tensions. ${ }^{19}$

Although the New Course was not adopted primarily as a concession to Western opinion, it was meant to contribute to a new climate for East-West negotiations, especially on the issue of German reunification. The effect must be contrasted with that of the Second Party Conference held a year earlier: the 1952 conference had undermined the credibility of Stalin's March 10 reunification proposal because the "construction of socialism" anticipated the speedy transformation of East Germany into a separate state, very different from the rest of Germany; the New Course, by contrast, seemed more compatible with the possibility of reunification.

There were certain dangers for the GDR in linking the New Course explicitly with the reunification effort. On the one hand, it was useful to let the West, particularly West German voters, interpret the New Course as evidence of Soviet willingness to permit reunification. On the other hand, Soviet interest in reunification could be interpreted in the GDR as a sign of diminished Soviet support for the East German regime. To a certain extent, this is in fact what happened. Reformist pressures from Moscow provoked rising hopes among the public and declining morale within the leadership of the GDR.20

The East German leadership was probably more sensitive than the Russians to the potentially destabilizing effect of reunification rumors. Neues Deutschland, the party newspaper, did not stress the possibility of reunification in its discussion of the New Course. By contrast, the East German news agency, ADN, in an announcement to the foreign press, emphasized the significance of the New Course for German reunification, ${ }^{21}$ as did the Soviet-controlled newspaper in East Berlin, Tägliche Rundschau. ${ }^{22}$

The sudden zigzags of policy proved too much for the shaky German Democratic Republic. On June 16 and 17, just one week after the announcement of the New Course, the country was shaken by a nationwide popular revolt, which was suppressed by Soviet forces. In the aftermath of the uprising, rival factions in the GDR tried to place the blame on each other: supporters of First Secretary Ulbricht attributed the uprising to the rising expectations engendered by the New Course; the anti-Ulbricht faction saw the revolt as a belated rebellion against the harsh policies of the Second Party Conference-the "con-

18. Heinz Brandt; Ein Traum der nicht entführbar ist (Munich: Paul List Verlag, 1967), p. 223.

19. Otto Grotewohl, "Die Gegenwärtige Lage und der Neue Kurs der Partei," in Der Neue Kurs und die Aufgaben der Partei (Berlin: Dietz Verlag, 1953), p. 26. 159.

20. Heinz Lippmann, Honecker (Cologne: Verlag Wissenschaft und Politik, 1971), p. $634 \mathrm{ff}$.

21. New York Times, June 11, 1953; see also Wettig, Die Entmilitarisierung, pp.

22. New York Times, June 14, 1953. 
struction of socialism." The confrontation was resolved by a compromise worked out under the scrutiny of Soviet authorities. The New Course remained a cornerstone of East German domestic policy, while Ulbricht, who had initially opposed the New Course, was retained in office. The phrase "construction of socialism" was restored to the official lexicon, but it now was used to describe only the general direction of the GDR's long-term development, not a particular program as in 1952. There was no return to the unpopular policies previously associated with the slogan "construction of socialism."23

Although the GDR stood by the substantial domestic reforms of the New Course, there was a greater effort to delineate clearly the limits of the reform program. The restoration of the slogan "construction of socialism" was intended to crush speculation within the GDR that the Soviet Union might be prepared to tolerate the eventual liquidation of the East German regime in the interest of German reunification. Unfortunately, from the Soviet point of view, such speculation was also discouraged in the West. Thus the uprising reduced the usefulness of the New Course in the Soviet reunification initiative. The uprising did not quite signify the end of the reunification effort, but it imposed tighter limits on Soviet declaratory policy and thus tended to undermine the credibility of the Soviet proposal.

The events of the summer contributed decisively to the failure of the East German and Soviet attempts to influence the September 1953 elections in West Germany. Despite a concerted effort by the GDR to present Adenauer's support for EDC as the greatest obstacle to German reunification, the government increased its majority at the polls while the Communist vote plummeted.

In short, Stalin's heirs, like their predecessor, offered an eventual Soviet concession in exchange for immediate Western concessions, that is, eventual reunification in exchange for immediate rejection of the EDC and recognition of the GDR. But the reunification initiative was subordinate to the need to retain control of East Germany. The New Course was presented intially as a possible step toward reunification, but only so long as this suggestion did not threaten the stability of the GDR. When the June uprising presented such a threat, the Russians responded with speedy clarification of the limits of the New Course, even though their firmness damaged the credibility of the reunification initiative. The preservation of the GDR took precedence over any potential Soviet advantage to be gained from Western interest in German reunification.

23. The slogan was resurrected at the July 1953 plenum (see Dokumente der SED, vol. 4 [Berlin: Dietz Verlag, 1954], pp. 436 ff.). 